\title{
D-chiro-Inositol is absorbed but not synthesised in rodents
}

\author{
Xiaobo Lin ${ }^{1}$, Lina $\mathrm{Ma}^{1}$, Chaya Gopalan ${ }^{2}$ and Richard E. Ostlund $\mathrm{Jr}^{1}{ }^{*}$ \\ ${ }^{1}$ Division of Endocrinology, Metabolism and Lipid Research, Department of Medicine, Washington University School of Medicine, \\ St Louis, MO 63110, USA \\ ${ }^{2}$ St Louis College of Pharmacy, St Louis, MO 63110, USA \\ (Received 14 November 2008 - Revised 1 May 2009 - Accepted 5 May 2009 - First published online 9 July 2009)
}

D-chiro-inositol (DCI) and pinitol (1D-3-O-methyl-chiro-inositol) are distinctive inositols reported to possess insulin-mimetic properties. DCIcontaining compounds are abundant in common laboratory animal feed. By GC-MS of $6 \mathrm{M}-\mathrm{HCl}$ hydrolysates, Purina Laboratory Rodent Diet 5001 (diet 5001) contained $0.23 \%$ total DCI by weight with most found in the lucerne and soya meal components. In contrast, only traces of L-chiro-inositol were observed. The DCI moiety was present in a water-soluble non-ionic form of which most was shown to be pinitol. To measure the absorption of dietary inositols, rats were fed diet 5001 in a balance study or given purified pinitol or $\left[{ }^{2} \mathrm{H}_{6}\right] \mathrm{DCI}$. More than $98 \%$ of the total DCI fed to rats as diet 5001, purified pinitol or $\left[{ }^{2} \mathrm{H}_{6}\right]$ DCI was absorbed from the gastrointestinal tract. Rats chronically on diet 5001 consumed $921 \mu \mathrm{mol}$ total $\mathrm{DCI} / \mathrm{kg}$ body weight per d but excreted less than $5.3 \%$ in the stools and urine, suggesting that the bulk was metabolised. The levels of pinitol or DCI in plasma, stools or urine remained relatively stable in mice fed Purina PicoLab ${ }^{\circledR}$ Rodent Diet 205053 over a 5 -week period, whereas these values declined to very low levels in mice fed a pinitol/DCI-deficient chemically defined diet. To test whether DCI was synthesised or converted from myo-inositol, mice were treated with heavy water or $\left[{ }^{2} \mathrm{H}_{6}\right]$ myo-inositol. DCI was neither synthesised endogenously from ${ }^{2} \mathrm{H}$-labelled water nor converted from $\left[{ }^{2} \mathrm{H}_{6}\right]$ myo-inositol. DCI and pinitol in rodents appear to be derived solely from the diet.

Pinitol: Insulin: Mass spectrometry: Defined diets

The mechanism of insulin action is still incompletely understood and the subject of active investigation. After insulin binds to its cell surface receptor, many metabolic pathways are activated. Interest in these secondary signalling systems has resulted in the isolation of certain inositol phosphoglycan molecules which mimic some actions of insulin, especially those related to glucose oxidation and lipid metabolism ${ }^{(1-5)}$. Interestingly, the inositol present in some of these putative insulin mediator preparations was predominantly or solely D-chiro-inositol (DCI) (Fig. 1(a)), an epimer of myo-inositol (MI) (Fig. 1(c)), which is the predominant mammalian inositol $^{(6,7)}$. DCI differs from MI only in the orientation of a single hydroxyl group (labelled 6 in both DCI and MI). It is this hydroxyl group by which MI is attached to phosphatidic acid in phosphatidylinositol. The prefix 'chiro' refers to the fact that this inositol has optically active D and L enantiomers. chiro-Inositol also has been identified in preparations derived from the phosphatidylinositol anchors of membrane proteins $^{(8-10)}$. Both the chemical structure and the occurrence of DCI in insulin signalling molecules suggest that it may have a physiological role in mammals. Pinitol (1D-3-O-methyl-chiro-inositol) is structurally related to DCI, having a methoxyl group at position 3 (Fig. 1(b)). Pinitol was originally described in 1855 as a component of the sugar pine tree ${ }^{(11)}$. It is also a prominent component of animal forage legumes ${ }^{(12)}$ and is found in beans including soyabeans $^{(13,14)}$.

Diabetic patients (both type 1 and type 2) have increased urinary excretion of DCI, the magnitude of which correlates with plasma glucose and glycated $\mathrm{Hb}$ levels ${ }^{(15)}$. Pima Indians with type 2 diabetes have low levels of muscle chiro-inositol ${ }^{(16)}$. A similar abnormality in chiro-inositol excretion is found in diabetic $\mathrm{db} / \mathrm{db}$ mice and streptozotocin diabetic rats $^{(17)}$. Although not all clinical trials have been positive ${ }^{(18)}$, at least some insulin-resistant patients appear to have responded to treatment with DCI or pinitol with improved insulin sensitivity ${ }^{(19,20)}$.

Studies of animal and human treatment with pinitol or DCI have been limited by lack of experimental control of dietary intake and incomplete knowledge of DCI metabolism. MI, a component of mixed diets ${ }^{(21)}$, has been shown to be actively absorbed in the small intestine of hamsters ${ }^{(22)}$ and also is synthesised from glucose $\mathrm{e}^{(23-25)}$. However, there is no information about DCI absorption, and previous work on the possible bioconversion of DCI from MI has not given consistent results. Inositol epimerase from bovine brain converted MI to neo- and scyllo-inositol but not to chiro-inositol ${ }^{(26)}$. In cockroach fat body extracts, however, epimerisation of MI

Abbreviations: DCI, D-chiro-inositol; diet 5001, Purina Laboratory Rodent Diet 5001; diet 5053, Purina PicoLab ${ }^{\circledR}$ Rodent Diet 20 5053; diet 5755, TestDiet ${ }^{\circledR} 5755$

Basal Diet; MI, myo-inositol.

* Corresponding author: Dr Richard E. Ostlund Jr, fax +1 314747 4471, email Rostlund@dom.wustl.edu 
<smiles>O[C@H]1[C@H](O)[C@H](O)[C@H](O)[C@@H](O)[C@H]1O</smiles>

Fig. 1. Structures of inositols: D-chiro-inositol (DCl) (a); pinitol (b); myo-inositol (c). $\mathrm{DCl}$ is numbered as recommended by the International Union of Pure and Applied Chemistry ${ }^{(34)}$. Pinitol and myo-inositol are numbered according to the convention for $\mathrm{DCl}$.

to chiro-inositol was observed ${ }^{(27)}$. Injection of ${ }^{3} \mathrm{H}$-labelled MI into rats showed conversion of MI to chiro-inositol as judged by counts co-migrating with chiro-inositol ${ }^{(28)}$.

In the present study we analysed dietary inositol contents of commercial animal diets and studied the absorption of pinitol and DCI and biosynthesis of DCI in rodents maintained on chemically defined diets.

\section{Materials and methods}

\section{Materials}

Diisopropylidene pinitol and L-chiro-inositol were gifts of Professor Laurens Anderson of the University of Wisconsin, Madison. Pinitol containing less than $1 \%$ DCI was prepared from its isopropylidene derivative by hydrolysis in $0.1 \mathrm{M}-\mathrm{HCl}$ for $1 \mathrm{~h}$ at $110^{\circ} \mathrm{C}$, followed by lyophilisation and recrystallisation from $90 \%$ ethanol ${ }^{(29)}$. DCI was purchased from Calbiochem. DL-1,2,3,4,5,6- $\left[{ }^{2} \mathrm{H}_{6}\right]$ chiro-inositol ${ }^{(30)}$ was the gift of Dr Ken Sasaki (Connaught Center for Biotechnology Research, Toronto, ON, Canada). 1,2,3,4,5,6- $\left[{ }^{2} \mathrm{H}_{6}\right] \mathrm{MI}$ was purchased from MSD Isotopes (Montreal, QC, Canada). $\left[{ }^{2} \mathrm{H}_{3}\right]$ pinitol labelled in the methyl radical was a gift of $\mathrm{Dr}$ Andrew Falshaw (Industrial Research Ltd, Lower Hutt, New Zealand). Ethanol-extracted casein (C3400) was purchased from Sigma (St Louis, MO, USA).

\section{Diets}

Purina Laboratory Rodent Diet 5001 (diet 5001) and Purina PicoLab Rodent Diet 205053 (diet 5053) were purchased from LabDiet (Richmond, IN, USA). Basal Diet 5755 (diet 5755; a chemically defined diet) was purchased from TestDiet (Richmond, IN, USA). Components of diet 5001 were kindly supplied by Dr Daniel Hopkins. The pinitol/DCI-deficient diet (Table 1) was based on diet 5755. The ingredients for both diets were dextrin, casein, sucrose, mineral mix, vitamin mix, cellulose, choline chloride, DL-methionine and fat. Maize oil $(5 \%)$ and lard (5\%) were used in diet 5755 whereas only soyabean oil (5\%) was used in our pinitol/DCI-deficient diet. Components of diet 5755 were analysed for total DCI and levels were generally very low. The original powdered cellulose contained $0.014 \mathrm{nmol}$ total DCI/mg and was replaced by Avicel $^{\circledR}$ cellulose (FMC Biopolymer, Philadelphia, PA, USA), which contained non-detectable total DCI.
Table 1. Pinitol/D-chiro-inositol-deficient diet formulation

\begin{tabular}{llr}
\hline Ingredients & Source & $\mathrm{g} / \mathrm{kg}$ \\
\hline Dextrin & TestDiet $^{*}$ & $393 \cdot 7$ \\
Casein & Sigma† & $248 \cdot 8$ \\
Sucrose & TestDiet & $200 \cdot 0$ \\
Soyabean oil & Sam's Clubł & $50 \cdot 0$ \\
Cellulose & FMC Biopolymer§ & $33 \cdot 2$ \\
Choline chloride & TestDiet $^{*}$ & $2 \cdot 0$ \\
DL-Methione & TestDiet $^{*}$ & $2 \cdot 0$ \\
Mineral mix\| & TestDiet $^{*}$ & $50 \cdot 0$ \\
Vitamin mixף & TestDiet $^{*}$ & $50 \cdot 0$
\end{tabular}

ppm, Parts per million.

${ }^{*}$ Richmond, IN, USA.

† St Louis, MO, USA.

$\ddagger$ Head Office: Bentonville, AR, USA.

$\S$ Philadelphia, PA, USA.

II Final concentration of mineral mix components in the diet, as provided by the manufacturer: $\mathrm{Ca}, 0.60 \% ; \mathrm{P}, 0.60 \%$, $\mathrm{K}$, $0.40 \% ; \mathrm{Mg}, 0.07 \% ; \mathrm{Na}, 0.21 \% ; \mathrm{Cl}, 0.24 \% ; \mathrm{F}, 5.0 \mathrm{ppm}$; $\mathrm{Fe}, 63.0 \mathrm{ppm}$; Zn, $21.0 \mathrm{ppm}$; Mn, $65.0 \mathrm{ppm}$; Cu, $15.0 \mathrm{ppm}$; Co, 3.2ppm; I, 0.57ppm; Cr, 3.0ppm; Mo, 0.82 ppm; Se, $0.23 \mathrm{ppm}$

I Final concentration of vitamin mix in the diet, as provided by the manufacturer: vitamin $A, 22.1 \mathrm{lU} / \mathrm{g}(12.1 \mu \mathrm{g} / \mathrm{g})$; vitamin $D_{3}$, $2.2 \mathrm{IU} / \mathrm{g}(0.055 \mu \mathrm{g} / \mathrm{g})$; vitamin E, $50.1 \mathrm{IU} / \mathrm{kg}(50.1 \mathrm{mg} / \mathrm{kg})$; vitamin $\mathrm{K}$, as menadione, $10.4 \mathrm{ppm}$; thiamin hydrochloride, $20.6 \mathrm{ppm}$; riboflavin, $20.0 \mathrm{ppm}$; niacin, $90.0 \mathrm{ppm}$; pantothenic acid, $55.0 \mathrm{ppm}$; folic acid, $4.0 \mathrm{ppm}$; pyridoxine, $16.5 \mathrm{ppm}$; biotin, $0.4 \mathrm{ppm}$; vitamin $\mathrm{B}_{12}, 20.0 \mu \mathrm{g} / \mathrm{kg}$; choline chloride, 1400 ppm; ascorbic acid, $0.0 \mathrm{ppm}$.

\section{Gas chromatography-mass spectrometry}

For inositol analysis in plasma and urine, ${ }^{2} \mathrm{H}$-labelled internal standards for DCI, MI and pinitol were added and they were then processed by protein precipitation and anion exchange adsorption and dried as described previously ${ }^{(15)}$. Urine samples were further purified by solid-phase extraction. They were taken up in $0.5 \mathrm{ml}$ water, applied to a $1.0 \mathrm{ml}$ Supelclean $^{\text {TM }}$ LC-18 SPE column (Supelco, Bellefonte, PA, USA) previously equilibrated with $2 \mathrm{ml}$ methanol, eluted with $2 \mathrm{ml}$ water and lyophilised.

Both free and total inositols in feed are reported. To isolate free inositols, dried mouse stool homogenate or $50 \mathrm{mg}$ samples of finely ground mouse chow received all three ${ }^{2} \mathrm{H}$-labelled internal standards and were extracted with $0.5 \mathrm{ml}$ water at room temperature for $12 \mathrm{~h}$. For total inositols, samples of ground mouse chow or dried stool homogenate received $0.5 \mathrm{ml} 6 \mathrm{M}-\mathrm{HCl}$ with ${ }^{2} \mathrm{H}$-labelled internal standards for DCI and $\mathrm{MI}$ and were heated at $110^{\circ} \mathrm{C}$ for $24 \mathrm{~h}$ in tightly sealed tubes. Total DCI contents measured by acid hydrolysis include free and complex DCI such as inositol glycans or phosphates and free and complex pinitol, since acid hydrolysis converts pinitol to DCI and hydrolyses complex inositols to free inositols. The acid hydrolysate was separated from charred residue, dried under $\mathrm{N}_{2}$ at $85^{\circ} \mathrm{C}$ and taken up in $0.5 \mathrm{ml}$ water. Samples were treated with anion exchange resins, passed over $6 \mathrm{ml}$ LC-18 solid phase extraction columns (Supelco), and dried.

Lyophilised samples were derivatised for GC-MS by incubation overnight with $10 \%$ pentafluoropropionyl imidazole in acetonitrile at $65^{\circ} \mathrm{C}$ and then separated on a $25 \mathrm{~m} \times 0.25 \mathrm{~mm}$ internal diameter Chirasil-Val fused silica capillary column with $0 \cdot 16 \mu \mathrm{m}$ film thickness (Alltech Associates, Deerfield, 
IL, USA). The oven temperature was kept at $80^{\circ} \mathrm{C}$ for $0.5 \mathrm{~min}$, then raised at a rate of $60^{\circ} \mathrm{C} / \mathrm{min}$ to $100^{\circ} \mathrm{C}$ and held for $4 \mathrm{~min}$, and again raised at a rate of $20^{\circ} \mathrm{C} / \mathrm{min}$ to a final temperature of $185^{\circ} \mathrm{C}$ and held for $3.5 \mathrm{~min}$. The effluent was analysed in an Agilent Technologies 5973 quadrupole mass spectrometer by negative-ion chemical ionisation MS using methane as the reagent gas (Hewlett Packard, Palo Alto, CA, USA). Selected ion monitoring was performed at $m / z 573$ and 576 (for natural and ${ }^{2} \mathrm{H}$-labelled pinitols, respectively) and at $m / z \quad 726$ and 731 (for natural and ${ }^{2} \mathrm{H}$-labelled chiro-inositols and MI).

The enrichment of ${ }^{2} \mathrm{H}$-labelled water in urine was determined following alkaline exchange with acetone according to the published protocol, except that hexane rather than chloroform was used in the exchange procedure $^{(31)}$. Exchanged acetone was separated isothermally at $60^{\circ} \mathrm{C}$ for $5 \mathrm{~min}$ on a $30 \mathrm{~m} \times 0.25 \mathrm{~mm}$ internal diameter DB17-MS capillary column with $0.25 \mu \mathrm{m}$ film thickness (J\&W Scientific, Folsom, CA, USA). Selected ion monitoring was performed at $\mathrm{m} / \mathrm{z} 58$ and 59 using electron impact ionisation mode $(70 \mathrm{eV})$. The incorporation of ${ }^{2} \mathrm{H}$ from ${ }^{2} \mathrm{H}$-labelled water into MI was calculated by mass isotope distribution analysis considering both ${ }^{2} \mathrm{H}$ and natural ${ }^{13} \mathrm{C}$ enrichment.

\section{Metabolic balance studies in rats fed Purina Rodent Diet 5001 or Basal Diet 5755}

For metabolic balance studies, male Sprague-Dawley rats weighing $400-500 \mathrm{~g}$ were fed diet 5001 for at least 1 month, then housed individually in metabolism cages and fed powdered diets consisting of either diet 5001 or diet 5755 for 1 week. Dietary consumption was measured and urine and faeces were collected for $24 \mathrm{~h}$. The total amount of DCI after $\mathrm{HCl}$ hydrolysis was measured by negative-ion chemical ionisation GC-MS, and DCI balance was computed as the difference between intake and output. Institutional and national guidelines for the care and use of animals were followed. All procedures involving animals were approved by the Washington University Animal Studies Committee.

\section{Effect of stool bacteria on faecal total D-chiro-inositol levels}

Equal amounts of stools from three rats fed diet 5001 were pooled and dispersed in $0 \cdot 15 \mathrm{M}-\mathrm{NaCl}$ to a concentration of $0.2 \mathrm{~g} / \mathrm{ml}$ and $\mathrm{MI}$ and glucose were added to final concentrations of $30 \mu \mathrm{M}$ and $5.5 \mathrm{~mm}$, respectively. Samples were incubated for $24 \mathrm{~h}$ at either $4^{\circ} \mathrm{C}$ (control for the measurements at $37^{\circ} \mathrm{C}$ ) or $37^{\circ} \mathrm{C}$ in anaerobic jars, after which internal standards were added and the samples were hydrolysed and processed by negative-ion chemical ionisation GC-MS for total DCI content.

\section{Absorption studies in rats fed Basal Diet 5755}

Three rats weighing 427 (SEM 27) g were housed individually in metabolism cages and fed diet 5755 for $3 \mathrm{~d}$. Pinitol, $51.5 \mu \mathrm{mol}(10 \mathrm{mg})$, was then given orally; urine and stools were collected for the following $2 \mathrm{~d}$ and analysed for total
DCI. Then $25 \mathrm{nmol}\left[{ }^{2} \mathrm{H}_{6}\right] \mathrm{DCI}$ was given orally followed by an additional $2 \mathrm{~d}$ of urine and stool collection.

\section{Inositol clearance over time in mice fed Purina PicoLab ${ }^{\circledR}$ Rodent Diet 205053 or the pinitol/D-chiro-inositol-deficient diet}

Male C57BL/6J mice were fed diet 5053 for 1 week before randomly being assigned to diet 5053 ( $n$ 8) or the pinitol/ DCI-deficient diet $(n 8)$ for up to 5 weeks. Food intake was recorded twice per week and body weight once per week. Plasma, stools and urine were obtained before the experimental assignment (week 0), and at 1,2 and 5 weeks after the diet assignment. For each time point, urine and stools were collected over a $24 \mathrm{~h}$ period in individual metabolism cages. Pinitol, DCI and MI levels in plasma, stools or urine were determined by GC-MS.

\section{Measurement of inositol biosynthesis in mice fed the pinitol/ $D$-chiro-inositol-deficient diet}

To measure endogenous inositol (DCI and MI) synthesis, male C57BL/6J mice ( $n$ 3) were maintained on the pinitol/DCIdeficient diet for 10 weeks. Then, mice were provided with drinking water containing $20 \%$ heavy water $\left({ }^{2} \mathrm{H}\right.$-labelled water, catalogue number 151882; Sigma-Aldrich) for 1 week to label the ring hydrogens of inositols, followed by $24 \mathrm{~h}$ urine collection in individual metabolism cages.

At 5 weeks later, $\left[{ }^{2} \mathrm{H}_{6}\right] \mathrm{MI}$ ( $1 \mathrm{mg}$ in water) was administered by intraperitoneal injection to each mouse ( $n 3$, maintained on the pinitol/DCI-deficient diet for 15 weeks before intraperitoneal injection) to determine whether MI is converted into DCI in vivo. Urine was collected for $24 \mathrm{~h}$ each before and after injection. Urine samples were processed and GC-MS was performed as described above.

\section{Statistical analyses}

Group data are reported as mean values with their standard errors. Two-way repeated-measures ANOVA was used to analyse diet, time and interactions between diet and time with SAS Proc GLM (version 9.2; SAS Institute, Cary, NC, USA). Multiple comparisons were performed using the Tukey adjustment.

\section{Results}

Total acid-released D-chiro-inositol content of Purina rodent chows

Total DCI measured by GC-MS after hydrolysis with $6 \mathrm{M}-\mathrm{HCl}$ at $110^{\circ} \mathrm{C}$ for $24 \mathrm{~h}$ was a prominent component of laboratory animal chows (Table 2). Chows 5001 and 5053 each contained more than $4 \mathrm{nmol}$ total $\mathrm{DCI} / \mathrm{mg}$. Diet 5001 contained 12.9 (SEM 1.2) nmol total $\mathrm{DCI} / \mathrm{mg}$ or $0.23 \%$ by weight. DCI was present in diet 5001 in an amount approximately two-thirds that of MI, which was 20.2 (SEM 0.7) $\mathrm{nmol} / \mathrm{mg}$ or $0.36 \%$ by weight following hydrolysis. Another rodent chow, chow 5053, currently used in our animal facility, contained comparable levels of total DCI at 10.94 (SEM 0.45) $\mathrm{nmol} / \mathrm{mg}$ (Table 2). Diet 5755 had only trace levels of 
Table 2. Nutrient composition of the diets*

\begin{tabular}{|c|c|c|c|c|}
\hline & Diet 5001† & Diet 5053† & Diet $5755 \ddagger$ & Pinitol/DCl-deficient diet \\
\hline \multicolumn{5}{|l|}{ By energy (\%) } \\
\hline Protein & $28 \cdot 0$ & $23 \cdot 6$ & $18 \cdot 6$ & $23 \cdot 7$ \\
\hline Fat & $12 \cdot 2$ & 11.9 & $22 \cdot 0$ & 11.9 \\
\hline Carbohydrates & $59 \cdot 8$ & 64.5 & $59 \cdot 3$ & 64.4 \\
\hline \multicolumn{5}{|l|}{ By weight (\%) } \\
\hline Protein & $23 \cdot 4$ & $20 \cdot 0$ & $19 \cdot 0$ & 22.5 \\
\hline Fat & 4.5 & 4.5 & $10 \cdot 0$ & $5 \cdot 0$ \\
\hline SFA & 1.50 & 0.84 & 2.72 & 0.74 \\
\hline MFA & 1.58 & 1.04 & 3.31 & 1.06 \\
\hline PUFA & 1.42 & $2 \cdot 61$ & 3.97 & 3.20 \\
\hline Carbohydrates & 49.9 & $54 \cdot 8$ & $60 \cdot 6$ & $61 \cdot 3$ \\
\hline Fibre & $5 \cdot 3$ & 4.7 & $4 \cdot 3$ & 4.6 \\
\hline \multicolumn{5}{|l|}{ Inositols (nmol/mg) } \\
\hline \multicolumn{5}{|l|}{ Free pinitol } \\
\hline Mean & NA & 7.09 & 0.0014 & 0.0008 \\
\hline SEM & NA & 0.02 & 0.0003 & 0.0001 \\
\hline \multicolumn{5}{|l|}{ Free $\mathrm{DCl}$} \\
\hline Mean & NA & $0 \cdot 16$ & ND\| & ND\| \\
\hline SEM & NA & 0.02 & ND & ND \\
\hline \multicolumn{5}{|l|}{ Total DCI } \\
\hline Mean & $12 \cdot 9$ & 10.94 & 0.0018 & 0.0012 \\
\hline SEM & 1.2 & 0.45 & 0.0001 & 0.0003 \\
\hline \multicolumn{5}{|l|}{ Free MI } \\
\hline Mean & NA & 1.96 & 0.75 & 0.62 \\
\hline SEM & NA & 0.09 & 0.03 & 0.01 \\
\hline \multicolumn{5}{|l|}{ Total MI } \\
\hline Mean & $20 \cdot 2$ & $41 \cdot 1$ & 1.07 & 0.68 \\
\hline SEM & 0.07 & 8.6 & 0.05 & 0.06 \\
\hline
\end{tabular}

Diet 5001, Purina Laboratory Rodent Diet 5001; diet 5053, Purina PicoLab ${ }^{\circledR}$ Rodent Diet 20 5053; diet 5755, TestDiet $^{\circledR} 5755$ Basal Diet; DCl, D-chiro-inositol; PFV, physiological fuel energy; NA, not analysed; ND, not detectable; MI, myo-inositol.

* The mouse chows and the pinitol/DCl-deficient diet ( $n 3$, about $50 \mathrm{mg}$ each) were weighed. Free (for pinitol, $\mathrm{DCl}$ and $\mathrm{MI}$ ) and total (for $\mathrm{DCl}$ and $\mathrm{MI}$ ) inositols were determined as described in Materials and methods. The rest of nutrient composition was from the manufacturers.

†Purchased from LabDiet (Richmond, IN, USA).

†Purchased from TestDiet (Richmond, IN, USA).

$\S$ Sum of decimal fractions of protein, fat and carbohydrates multiplied by $16 \cdot 8,37 \cdot 7$ and $16 \cdot 8 \mathrm{~kJ} / \mathrm{g}$, respectively.

\| The limit of detection for $\mathrm{DCl}$ is $0.0003 \mathrm{nmol} / \mathrm{mg}$.

total DCI and these levels were reduced even further in the pinitol/DCI-deficient diet.

Analyses of chow components showed that maize, wheat, meat, fish and dairy products contributed relatively little DCI (Table 3). However, total DCI was very high in the leguminous components of lucerne and soyabean meal in which it constituted 1.3 and $1.0 \%$ of weight, respectively, or more than fifty times as much as in other chow components. L-chiro-Inositol, in contrast, was very low in all ingredients.

The molecular form of DCI in diet 5001 was further investigated. Finely ground chow was suspended at room temperature in $1 \mathrm{M}-\mathrm{HCl}$, then extracted and partitioned by the method of Bligh \& Dyer ${ }^{(32)}$ to yield aqueous and organic fractions. Less than $1 \%$ of the total DCI was found in the organic fraction; in contrast, $83 \%$ was recovered in the aqueous fraction with the remainder in the insoluble residue. Thus, substantial amounts of DCI did not appear to be present in phospholipids and DCI was present predominantly in the water-soluble form. Only $6 \%$ of the total DCI was measurable without prior strong acid hydrolysis. The species containing DCI did not appear to be ionic (such as a phytate) because there was no change in the measured concentration when the sample was treated with an AG 501-X8(D) mixed bed ion exchange resin.
Metabolic balance studies in rats fed Purina Rodent Diet 5001 or Basal Diet 5755

Rats chronically fed diet 5001 consumed $921 \mu \mathrm{mol}$ total $\mathrm{DCI} / \mathrm{kg}$ body weight per $\mathrm{d}$ or $0.17 \mathrm{~g}$ total $\mathrm{DCI} / \mathrm{kg}$ body weight per d (Table 4 ). Only $0.7 \%$ of total DCI intake was found in the stool output, suggesting that gastrointestinal absorption was essentially complete. Urinary output was only $4.6 \%$ of that consumed. The total excretion from the urine and stools represents $5.3 \%$ of the total DCI intake, suggesting that the majority of the dietary inositols was metabolised. Thus, total DCI balance was strongly positive at 872.5 (SEM 79.0) $\mu \mathrm{mol} / \mathrm{kg}$ body weight per $\mathrm{d}$.

\section{Effect of stool bacteria on faecal total D-chiro-inositol levels}

Since bacterial degradation or production of DCI in the gastrointestinal tract could have influenced these experiments, rat stool samples were fortified with MI and glucose (possible metabolic precursors of DCI) and then incubated at $37^{\circ} \mathrm{C}$ anaerobically for $24 \mathrm{~h}$. A large amount of gas was produced indicating active bacterial metabolism, but little effect on measured total DCI levels was seen. There was a $9.5 \%$ decrease in total DCI after $37^{\circ} \mathrm{C}$ incubation 
Table 3. Total chiro-inositol content of components of Purina Rodent Diet 5001

\begin{tabular}{lcc}
\hline Components (nmol/mg dry weight) & D-chiro-Inositol & L-chiro-Inositol \\
\hline Lucerne* $^{*}$ & & \\
Mean & 74.7 & $-\dagger$ \\
$\quad$ SEM & 5.2 & - \\
Soyabean meal & \\
$\quad$ Mean & 54.1 & $-\dagger$ \\
SEM & 4.1 & - \\
Wheat germ & 1.011 & 0.008 \\
Ground oats & 0.758 & 0.028 \\
Fish meal & 0.676 & 0.012 \\
Ground beet pulp & 0.248 & 0.003 \\
Meat meal & 0.058 & 0.004 \\
Yeast & 0.049 & 0.014 \\
Middlings & 0.049 & 0.015 \\
Ground maize & 0.044 & 0.003 \\
Bleachable fat & 0.018 & 0.001 \\
Molasses & 0.010 & 0.004 \\
Whey & 0.009 & 0.001 \\
\hline *Values for lucerne and soya for six replicates. & \\
†L-chiro-Inositol could not be measured accurately in the presence of the large \\
amount of D-chiro-inositol but it constituted less than $2 \%$ of D-chiro-inositol.
\end{tabular}

(10.54 (SEM 0.27) nmol $/ \mathrm{ml}$ at $4{ }^{\circ} \mathrm{C} v .9 .85($ SEM $0 \cdot 19) \mathrm{nmol} / \mathrm{ml}$ at $\left.37^{\circ} \mathrm{C} ; P=0.052\right)$, suggesting that a small amount of degradation might have occurred. Stool L-chiro-inositol was unchanged by incubation $\left(1 \cdot 11(\operatorname{SEM} 0 \cdot 36) \mathrm{nmol} / \mathrm{ml}\right.$ at $4^{\circ} \mathrm{C} v$. $1.32(\mathrm{SEM} 0 \cdot 11) \mathrm{nmol} / \mathrm{ml}$ at $\left.37^{\circ} \mathrm{C}\right)$. Bacterial degradation or metabolism, therefore, could not account for the quantitative reduction of total DCI in stools compared with the diet.

\section{Absorption studies in rats fed Basal Diet 5755}

The gastrointestinal absorption of purified pinitol was studied next (Table 5). At $3 \mathrm{~d}$ before the experiment, rats were switched from diet 5001 to diet 5755 low in total DCI in order to reduce excretion of total DCI to approximately $0.5 \mu \mathrm{mol} / \mathrm{kg}$ body weight per $\mathrm{d}$. Then $10 \mathrm{mg}$ pinitol (containing $51.5 \mu \mathrm{mol}$ total DCI) was given orally and the faecal and urinary excretion of total DCI was measured. Most of

Table 4. Metabolic balance of total D-chiro-inositol (DCl) in rats fed Purina Rodent Diet 5001*

(Mean values with their standard errors)

\begin{tabular}{|c|c|c|}
\hline & Mean & SEM \\
\hline Rat weight (g) & 471 & 35 \\
\hline Chow consumed $(\mathrm{g} / \mathrm{d})$ & 33.2 & 1.6 \\
\hline Stools produced $(\mathrm{g} / \mathrm{d})$ & 9.4 & 0.7 \\
\hline $\mathrm{DCl}$ intake $(\mu \mathrm{mol} / \mathrm{kg}$ body weight per $\mathrm{d})$ & 921.0 & 84.0 \\
\hline \multicolumn{3}{|l|}{$\mathrm{DCl}$ output $(\mu \mathrm{mol} / \mathrm{kg}$ body weight per $\mathrm{d}$ ) } \\
\hline Stools & $6 \cdot 2$ & 0.9 \\
\hline Urine & $42 \cdot 3$ & 4.2 \\
\hline Total & 48.5 & $8 \cdot 1$ \\
\hline $\mathrm{DCl}$ balance $(\mu \mathrm{mol} / \mathrm{kg}$ body weight per $\mathrm{d})$ & $872 \cdot 5$ & $79 \cdot 0$ \\
\hline
\end{tabular}

* Rats $(n 3)$ were fed Purina Rodent Diet 5001 for at least 1 month and housed in individual metabolism cages for 1 week. Dietary consumption was measured and urine and faeces were collected for $24 \mathrm{~h}$. The total amount of $\mathrm{DCl}$ after $\mathrm{HCl}$ hydrolysis was measured by negativeion chemical ionisation GC-MS, and DCI balance was computed as the difference between intake and output. the material eliminated was excreted on day 1 when faecal loss was $0.9 \%$ of intake and urinary loss was $21 \%$. These data suggest that pinitol is absorbed from the gastrointestinal tract and most is retained or metabolised. That somewhat more total DCI appeared in urine $(21 \%)$ compared with diet 5001 feeding (4.6\%; Table 4) may be due to the large single pinitol bolus administered. The day after pinitol feeding, total excretion in urine and faeces was similar to baseline.

Similar results were obtained when labelled free DCI tracer was given orally (Table 5). Absorption, estimated by recovery of $\left[{ }^{2} \mathrm{H}_{6}\right]$ DCI in the stools for $2 \mathrm{~d}$, was $98 \%$. The urinary output was only $14 \%$ of that administered, consistent with incomplete urinary excretion.

\section{Inositol clearance over time in mice fed Purina PicoLab ${ }^{\circledR}$} Rodent Diet 205053 or the pinitol/D-chiro-inositol-deficient diet

After a more defined diet was developed, we studied the clearance of inositols over a longer period of time. There were time and diet effects and interactions between time and diet effects on the food intake (Fig. 2(a)) and body weight (Fig. 2(b)). Food intakes (Fig. 2(a)) and body weights (Fig. 2(b)) were statistically different at 1, 2, 3, 4 and 5 weeks between the two diets.

Both pinitol (Fig. 3(a), (c) and (e)) and DCI (Fig. 3(b), (d) and (f)) in plasma, stools or urine remained relatively stable over the 5-week period for the mice fed diet 5053. In contrast, both pinitol and DCI in these various compartments declined rapidly to a very low level over the 5-week period in mice fed the pinitol/DCI-deficient diet. Repeated-measures ANOVA showed that there was a diet effect on pinitol and DCI concentrations in plasma, stools or urine (Fig. 3). This indicates that the diet plays an important role in pinitol or DCI levels. A time effect was observed for all measurements except for stool pinitol, stool DCI or urine DCI. A time and diet interaction was seen for all parameters except for stool DCI. The differences at weeks 1, 2 and 5 between diet 5053 and the pinitol/DCI-deficient diet in all inositol measurements were statistically significant $(P<0 \cdot 001)$.

\section{Endogenous D-chiro-inositol/myo-inositol biosynthesis from ${ }^{2} \mathrm{H}$-labelled water in mice fed the pinitol/ D-chiro-inositol-deficient diet}

To determine whether the carbon ring hydrogen atoms of DCI were synthesised endogenously from water, male C57BL/6J mice ( $\left.\begin{array}{ll}n & 3\end{array}\right)$ were fed the pinitol/DCI-deficient diet for 10 weeks and received drinking water containing $20 \%(\mathrm{w} / \mathrm{w})$ ${ }^{2} \mathrm{H}$-labelled water for 1 week followed by a $24 \mathrm{~h}$ urine collection while housed in metabolism cages. The resulting concentration of ${ }^{2} \mathrm{H}$-labelled water in urine was 8.70 (SEM 0.52 ) $\%$ as determined by equilibration with acetone followed by GC-MS. Neither natural nor ${ }^{2} \mathrm{H}$-labelled DCI could be detected in the urine $(<0.0067 \mathrm{nmol} / \mathrm{ml})$. In contrast, ${ }^{2} \mathrm{H}$-labelled MI was present in the urine and it was calculated that 34.4 (SEM 2.8) \% of urinary MI was derived by biosynthesis from body water. 
Table 5. Gastrointestinal absorption of pinitol and $\left[{ }^{2} \mathrm{H}_{6}\right] \mathrm{D}$-chiro-inositol (DCl) in rats fed Basal Diet $5755^{\star}$

(Mean values with their standard errors)

\begin{tabular}{|c|c|c|c|c|c|c|c|c|}
\hline & \multicolumn{2}{|c|}{ Dietary intake } & \multicolumn{2}{|c|}{ Faecal output } & \multicolumn{2}{|c|}{ Urinary output } & \multicolumn{2}{|c|}{ Total output } \\
\hline & Mean & SEM & Mean & SEM & Mean & SEM & Mean & SEM \\
\hline \multicolumn{9}{|c|}{ Pinitol feeding } \\
\hline \multicolumn{9}{|c|}{ Total DCl ( $\mu \mathrm{mol} / \mathrm{kg}$ body weight per $\mathrm{d})$} \\
\hline Pre-pinitol & 0.09 & 0.02 & 0.07 & 0.02 & 0.48 & 0.31 & 0.54 & 0.31 \\
\hline Pinitol, day 1 & 122 & 7.4 & $1 \cdot 11$ & 0.53 & $26 \cdot 0$ & $1 \cdot 7$ & $27 \cdot 11$ & 0.56 \\
\hline Pinitol, day 2 & 0.07 & 0.01 & $0 \cdot 10$ & 0.01 & 0.38 & $0 \cdot 11$ & 0.47 & $0 \cdot 12$ \\
\hline$\left[{ }^{2} \mathrm{H}_{6}\right] \mathrm{DCl}$ feeding & & & & & & & & \\
\hline \multicolumn{9}{|c|}{ Free $\left[{ }^{2} \mathrm{H}_{6}\right] \mathrm{DCl}(\mathrm{nmol} / \mathrm{kg}$ body weight per d) } \\
\hline Day 1 & $59 \cdot 1$ & $3 \cdot 6$ & 0.15 & $0 \cdot 1$ & 4.0 & 0.4 & $4 \cdot 2$ & 0.2 \\
\hline Day 2 & ND & & 1.0 & 1.0 & $4 \cdot 3$ & $0 \cdot 1$ & $5 \cdot 3$ & $1 \cdot 1$ \\
\hline
\end{tabular}

ND, not detectable.

* Three rats weighing $427 \pm 27 \mathrm{~g}$ were housed individually in metabolism cages and fed Purina Basal Diet 5755 for $3 \mathrm{~d}$. Pinitol, $51.5 \mu \mathrm{mol}(10 \mathrm{mg})$, was given orally with urine and stools collected for the following $2 \mathrm{~d}$, which were analysed for total $\mathrm{DCl}$. Then $25 \mathrm{nmol}\left[{ }^{2} \mathrm{H}_{6}\right] \mathrm{DCl}$ was given orally, followed by an additional $2 \mathrm{~d}$ of urine and stool collection. No $\left[{ }^{2} \mathrm{H}_{6}\right] \mathrm{DCl}$ was detectable before isotope administration.

Conversion of myo-inositol to D-chiro-inositol in mice fed the pinitol/D-chiro-inositol-deficient diet

Male C57BL/6J mice ( $n$ 3) were maintained on the chemically defined pinitol/DCI-deficient diet for 15 weeks and then given $1.0 \mathrm{mg}\left[{ }^{2} \mathrm{H}_{6}\right] \mathrm{MI}$ by intraperitoneal injection. Following a $24 \mathrm{~h}$ isotope equilibration period, urine was collected in individual metabolism cages. $\left[{ }^{2} \mathrm{H}_{6}\right] \mathrm{MI}$ constituted 38.7 (SEM 11.5 ) \% of urinary MI after labelling, which indicated a large enrichment of the endogenous MI pool. Ionic masses corresponding to natural DCI $(\mathrm{m} / \mathrm{z} 726)$ through to fully labelled DCI $(\mathrm{m} / \mathrm{z}$ 731) were scanned, but no natural DCI or DCI with any amount of ${ }^{2} \mathrm{H}$ labelling was detected $(<0.0067 \mathrm{nmol} / \mathrm{ml})$.

\section{Discussion}

Total DCI levels were unexpectedly high in common laboratory animal chows and constituted $0.23 \%$ of the weight of diet 5001 (Table 2). The amounts consumed by animals were very large; for example, rats chronically ingested $166 \mathrm{mg}$ total DCI/ $\mathrm{kg}$ body weight per $\mathrm{d}$ while on diet 5001
(Table 4). Thus, a potential source of DCI is abundant in laboratory animal diets, principally in the legumes lucerne and soyabeans, which are ingredients of many commercial laboratory animal chows. However, meat and other animal products contained little total DCI. L-chiro-Inositol was present only in small amounts relative to DCI (Table 3). In lucerne and soyabeans, at least $98 \%$ of the total chiro-inositol was the D-enantiomer. In diet 5053, only $1.5 \%$ of the DCI was present in the free form, whereas $65 \%$ was found in free pinitol. Another $33.5 \%$ of DCI is in complex forms such as glycosides liberated by acid hydrolysis. In contrast to common rodent chows, diet 5755 and our pinitol/DCIdeficient diet had only trace amounts of total DCI (Table 2).

In the equilibrium state on diet 5001, there was a markedly positive total DCI balance of $872.5 \mu \mathrm{mol} / \mathrm{kg}$ body weight per d (Table 4). DCI must have been metabolised, since only about $5.3 \%$ was recovered in the stools $(0.7 \%)$ and urine (4.6\%). The complete absorption $(99.3 \%)$ of total DCI suggests that both free and complex forms of pinitol or DCI were absorbed from the diet. Their complete absorption from the gastrointestinal tract was further confirmed by using purified pinitol and
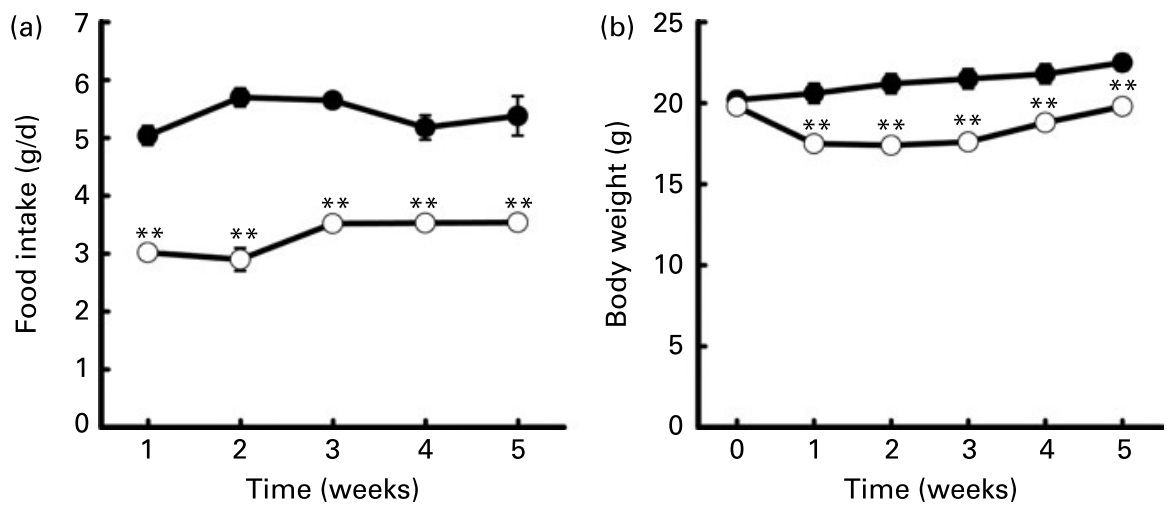

Fig. 2. Food intakes (a) and body weights (b) of mice fed Purina PicoLab ${ }^{\circledR}$ Rodent Diet 205053 (diet 5053) (•) or a pinitol/D-chiro-inositol (DCI)-deficient diet (O). Male C57BL/6J mice (eight mice per diet) were fed diet 5053 or the pinitol/DCl-deficient diet for 5 weeks. Food intake was measured twice per week and the average represents weekly food intake $(\mathrm{g} / \mathrm{d})$. Body weight was determined at the beginning and once per week. Values are means, with standard errors represented by vertical bars. ${ }^{* *}$ Mean value was significantly different from that of the mice fed diet $5053(P<0.001)$. Effects of diet $(P=0.0002)$, time $(P<0.0001)$ and interactions between time and diet $(P<0.0001)$ were statistically significant. 

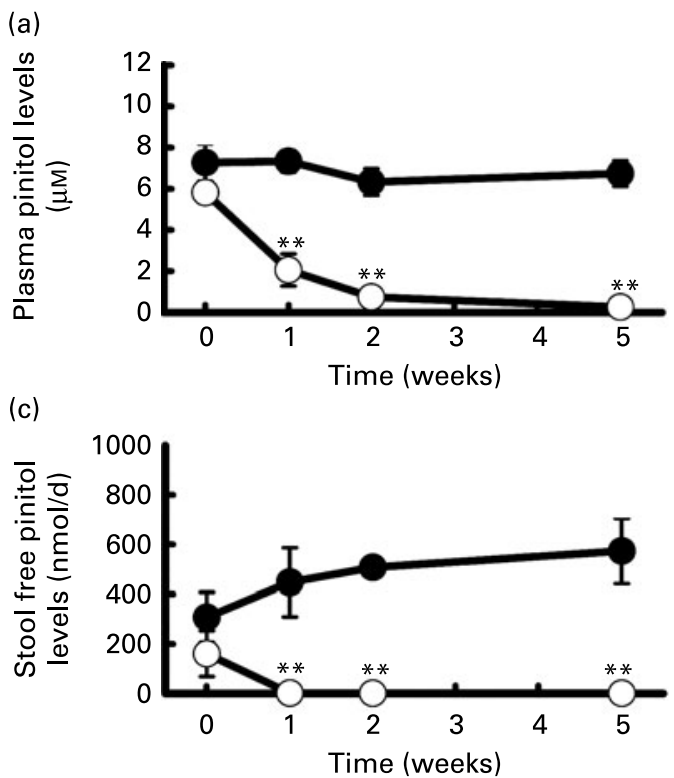

(e)

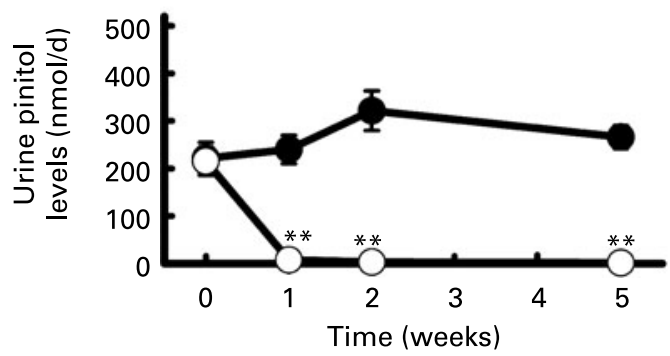

(b)

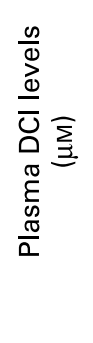

(d)

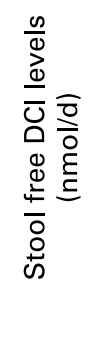

(f)

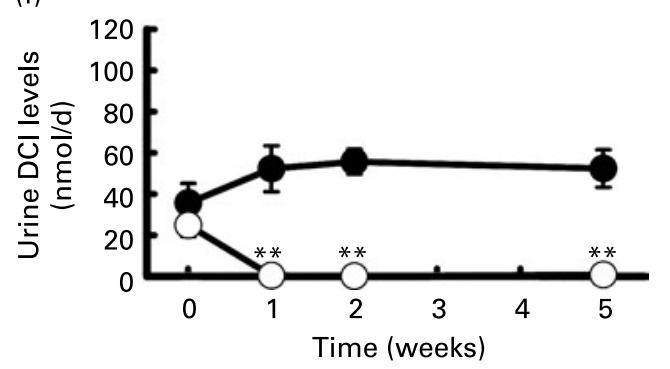

Fig. 3. Plasma, stool and urine inositols over time in mice fed Purina PicoLab ${ }^{\circledR}$ Rodent Diet 205053 (diet 5053) (•) or a pinitol/D-chiro-inositol (DCl)-deficient diet (O): plasma pinitol (a); plasma DCl (b); stool free pinitol (c); stool free DCl (d); urine pinitol (e); urine DCl (f). Male C57BL/6J mice (eight mice per diet) were fed diet 5053 or the pinitol/DCl-deficient diet for 5 weeks. Blood, urine and stools were obtained at 0, 1,2 and 5 weeks. Pinitol and DCl were analysed as described in Materials and methods. Values are means, with standard errors represented by vertical bars. ${ }^{\star \star}$ Mean value was significantly different from that of the mice fed diet $5053(P<0.001)$.

$\left[{ }^{2} \mathrm{H}_{6}\right] \mathrm{DCI}$, since less than $2 \%$ of the orally administered material was recovered in the stools (Table 5). More urinary output was observed on day 1 with feeding the natural pinitol than with the oral administration of $\left[{ }^{2} \mathrm{H}_{6}\right] \mathrm{DCI}$, suggesting that their metabolic kinetics differed.

It has been reported previously that soil bacteria transform labelled MI into chiro-inositol ${ }^{(30)}$. Although the extent of conversion was small $(4 \%$ over $12 \mathrm{~d})$, the possibility of bacterial synthesis or degradation of chiro-inositol in the large bowel was considered in our experiments under anaerobic incubation mimicking colonic fermentation. However, no net synthesis of DCI was found and only a small amount of DCI was degraded. Faecal bacteria do not appear, therefore, to be an important source of DCI in these animals.

Since pinitol is of plant origin ${ }^{(33)}$, it is expected to come exclusively from the diet. Thus pinitol in the plasma, stools or urine fell rapidly to a very low level over the 5-week period after switching from diet 5053 to the pinitol/DCIdeficient diet (Fig. 3(a), (c) and (e)). By contrast, pinitol levels in the same three compartments remained relatively stable when mice were fed diet 5053 (Fig. 3(a), (c) and (e)). Similarly, DCI fell rapidly to an extremely low level in the plasma, stools or urine of mice fed the pinitol/DCI-deficient diet, in contrast to relatively stable levels of these inositols in mice fed diet 5053 (Fig. 3(b), (d) and (f)). In fact, plasma, stools or urinary levels of pinitol or DCI were not detectable in mice fed the pinitol/DCI-deficient diet for 10 weeks. These results strongly suggest that DCI in body fluids derives from the diet and not from endogenous biosynthesis. Indeed, ${ }^{2} \mathrm{H}$-labelled water was not incorporated into ${ }^{2} \mathrm{H}$-labelled DCI, indicating no endogenous synthesis of DCI from body water hydrogen. In contrast, $34.4 \%$ of urinary MI was synthesised from ${ }^{2} \mathrm{H}$-labelled water, consistent with endogenous synthesis of MI in the literature ${ }^{(23)}$.

Bioconversion of MI to DCI appears not to occur in mice. ${ }^{2} \mathrm{H}$-labelled DCI was not detected in the urine of mice $24 \mathrm{~h}$ after intraperitoneal injection of $\left[{ }^{2} \mathrm{H}_{6}\right]$ MI. The injected $\left[{ }^{2} \mathrm{H}_{6}\right]$ MI constituted 38.7 (SEM 11.5 ) \% of urinary MI, indicating good enrichment of the putative precursor. Inconsistent results have been obtained in the past regarding conversion of MI to DCI. Inositol epimerase from bovine brain led to conversion of MI to neo- and scyllo-inositol but not chiro-inositol ${ }^{(26)}$. In cockroach fat body extracts, however, epimerisation of MI to chiro-inositol was observed ${ }^{(27)}$. More recently, Pak et al. injected $37 \mathrm{MBq}$ of $\left[{ }^{3} \mathrm{H}\right] \mathrm{MI}$ intraperitoneally into rats over $3 \mathrm{~d}$ and found that it was converted to radioactive counts that co-migrated with chiro-inositol ${ }^{(28)}$. The percentage conversion was very large, $8 \%$ in blood, 
$9 \%$ in liver and $36 \%$ in urine. However, DCI natural abundance of total inositols (sum of chiro-inositol and MI) is only $0.4 \%$ in plasma and $2.3 \%$ of urinary inositols in humans ${ }^{(15)}$. Furthermore, the ratio of basal (when all mice were on diet 5053) urinary DCI to urinary MI was barely $10.0 \%$ in the present study. This raises the possibility that some of the counts co-migrating with chiro-inositol on paper chromatograms may not have been chiro-inositol. Furthermore, the method used did not distinguish D- from L-chiro-inositol ${ }^{(28)}$

Our time-course study in mice comparing diet 5053 and the pinitol/DCI-deficient diet showed little change in body weight in either group over 5 weeks. However, mice in the pinitol/ DCI-deficient diet weighed less (Fig. 2(b)) and had less food intake (Fig. 2(a)) when compared with those on diet 5053. We speculate that this could be due to differences in MI, DCI or other nutrients, or to reduced palatability of the pinitol/ DCI-deficient diet. This experiment was performed to test whether or not DCI was synthesised endogenously rather than testing the function of DCI in the diet, which requires further research.

In conclusion, pinitol and DCI are present in large amounts in rodent chow diets and they are avidly absorbed from chow 5001. DCI was not synthesised in vivo or converted from $\left[{ }^{2} \mathrm{H}_{6}\right] \mathrm{MI}$, suggesting that, like pinitol, it derives solely from the diet. The present study suggests that dietary control of inositols should be considered for future research in diabetes and insulin resistance. The chemically defined diet 5755 and the pinitol/DCI-deficient diet described here establish a deficient baseline for future control studies, and are suitable for the determination of the effects of DCI and pinitol on glucose and lipid metabolism.

\section{Acknowledgements}

The present study was supported by a National Institutes of Health (NIH) grant (R01 DK58698) and the Washington University Mass Spectrometry Resource (RR00954), Diabetes Research and Training Center (DK20579) and Clinical Nutrition Research Center (DK56341).

The contribution of each author was: R. E. O., design and writing; X. L., design, performance of experiments, statistical analysis of data, and writing; L. M., performance of experiments, GC-MS analysis of samples; C. G., performance of experiments and writing.

The authors declare no conflicts of interest.

\section{References}

1. Romero G, Luttrell L, Rogol A, et al. (1988) Phosphatidylinositol-glycan anchors of membrane proteins: potential precursors of insulin mediators. Science 240, 509-511.

2. Saltiel AR (1990) Second messengers of insulin action. Diabetes Care 13, 244-256.

3. Mato JM, Kelly KL, Abler A, et al. (1987) Identification of a novel insulin-sensitive glycophospholipid from H35 hepatoma cells. J Biol Chem 262, 2131-2137.

4. Saltiel AR, Fox JA, Sherline P, et al. (1986) Insulin-stimulated hydrolysis of a novel glycolipid generates modulators of cAMP phosphodiesterase. Science 233, 967-972.
5. Kunjara S, McLean P, Greenbaum AL, et al. (2008) Insight into the role of inositol phosphoglycans in insulin response and the regulation of glucose and lipid metabolism illustrated by the response of adipocytes from two strains of rats. Mol Genet Metab 94, 263-266.

6. Mato JM, Kelly KL, Abler A, et al. (1987) Partial structure of an insulin-sensitive glycophospholipid. Biochem Biophys Res Commun 146, 764-770.

7. Larner J, Huang LC, Schwartz CF, et al. (1988) Rat liver insulin mediator which stimulates pyruvate dehydrogenase phosphate contains galactosamine and D-chiroinositol. Biochem Biophys Res Commun 151, 1416-1426.

8. Futerman AH, Low MG, Ackermann KE, et al. (1985) Identification of covalently bound inositol in the hydrophobic membrane-anchoring domain of Torpedo acetylcholinesterase. Biochem Biophys Res Commun 129, 312-317.

9. Low MG, Futerman AH, Ackermann KE, et al. (1987) Removal of covalently bound inositol from Torpedo acetylcholinesterase and mammalian alkaline phosphatases by deamination with nitrous acid. Evidence for a common membrane-anchoring structure. Biochem J 241, 615-619.

10. Walter EI, Roberts WL, Rosenberry TL, et al. (1990) Structural basis for variations in the sensitivity of human decay accelerating factor to phosphatidylinositol-specific phospholipase C cleavage. J Immunol 144, 1030-1036.

11. Berthelot M (1856) Pinitol. Compt Rend 41, 392.

12. Smith AE \& Phillips DV (1980) Ocurrence of pinitol in foliage of several forage legumes species. Crop Sci 20, 75-77.

13. Phillips DV, Dougherty DE \& Smith AE (1982) Cyclitols in soybean. J Agric Food Chem 30, 456-458.

14. Streeter JG (1980) Carbohydrates in soybean nodules: II. Distribution of compounds in seedlings during the onset of nitrogen fixation. Plant Physiol 66, 471-476.

15. Ostlund RE Jr, McGill JB, Herskowitz I, et al. (1993) D-chiro-Inositol metabolism in diabetes mellitus. Proc Natl Acad Sci U S A 90, 9988-9992.

16. Kennington AS, Hill CR, Craig J, et al. (1990) Low urinary chiro-inositol excretion in non-insulin-dependent diabetes mellitus. N Engl J Med 323, 373-378.

17. Kawa JM, Przybylski R \& Taylor CG (2003) Urinary chiroinositol and myo-inositol excretion is elevated in the diabetic $\mathrm{db} / \mathrm{db}$ mouse and streptozotocin diabetic rat. Exp Biol Med (Maywood) 228, 907-914.

18. Davis A, Christiansen M, Horowitz JF, et al. (2000) Effect of pinitol treatment on insulin action in subjects with insulin resistance. Diabetes Care 23, 1000-1005.

19. Iuorno MJ, Jakubowicz DJ, Baillargeon JP, et al. (2002) Effects of D-chiro-inositol in lean women with the polycystic ovary syndrome. Endocr Pract 8, 417-423.

20. Kim MJ, Yoo KH, Kim JH, et al. (2007) Effect of pinitol on glucose metabolism and adipocytokines in uncontrolled type 2 diabetes. Diabetes Res Clin Pract 77, Suppl. 1, S247-S251.

21. Holub BJ (1986) Metabolism and function of myo-inositol and inositol phospholipids. Annu Rev Nutr 6, 563-597.

22. Caspary WF \& Crane RK (1970) Active transport of myoinositol in hamster small intestine. Naunyn Schmiedebergs Arch Pharmakol 266, 309-310.

23. Daughaday WH, Larner J \& Hartnett C (1955) The synthesis of inositol in the immature rat and chick embryo. J Biol Chem 212, 869-875.

24. Clements RS Jr \& Diethelm AG (1979) The metabolism of myo-inositol by the human kidney. J Lab Clin Med 93, 210-219.

25. Hauser G \& Finelli VN (1963) The biosynthesis of free and phosphatide myo-inositol from glucose by mammalian tissue slices. J Biol Chem 238, 3224-3228. 
26. Hipps PP, Ackermann KE \& Sherman WR (1982) Inositol epimerase-inosose reductase from bovine brain. Methods Enzymol 89, 593-598.

27. Hipps PP, Sehgal RK, Holland WH, et al. (1973) Identification and partial characterization of inositol: NAD + epimerase and inosose: $\mathrm{NAD}(\mathrm{P}) \mathrm{H}$ reductase from the fat body of the American cockroach, Periplaneta americana L. Biochemistry $\mathbf{1 2}$, 4705-4712.

28. Pak Y, Huang LC, Lilley KJ, et al. (1992) In vivo conversion of $\left[{ }^{3} \mathrm{H}\right]$ myoinositol to $\left[{ }^{3} \mathrm{H}\right]$ chiroinositol in rat tissues. J Biol Chem 267, 16904-16910.

29. Anderson AB, MacDonald DL \& Fischer HOL (1952) The structure of pinitol. J Am Chem Soc 74, 1479-1480.

30. Sasaki K, Balza F \& Taylor IEP (1987) Preparative-scale separation by anion-exchange chromatography of six per-Cdeuterated inositol epimers produced during $\mathrm{C}-{ }^{1} \mathrm{H}-\mathrm{C}-{ }^{2} \mathrm{H}$ exchange reactions with raney nickel in deuterium oxide. Carbohydrate Res 166, 171-180.

31. McCabe BJ, Bederman IR, Croniger C, et al. (2006) Reproducibility of gas chromatography-mass spectrometry measurements of ${ }^{2} \mathrm{H}$ labeling of water: application for measuring body composition in mice. Anal Biochem 350, 171-176.

32. Bligh EG \& Dyer WJ (1959) A rapid method of total lipid extraction and purification. Can J Biochem Physiol 37, 911-917.

33. Vernon DM \& Bohnert HJ (1992) A novel methyl transferase induced by osmotic stress in the facultative halophyte Mesembryanthemum crystallinum. EMBO J 11, 2077-2085.

34. Anonymous (1976) IUPAC Commission on the Nomenclature of Organic Chemistry (CNOC) and IUPAC-IUB Commission on Biochemical IUPAC Nomenclature (CBN). Nomenclature of cyclitols. Recommendations, 1973. Biochem J 153, 23-31. 